\title{
GREEN CHEMISTRY FOR THE PREPARATION OF BIO-BASED OIL FROM CATFISH FAT USING A CAVITATION SYSTEM
}

\author{
Hong Tran Thi ${ }^{1,2}$, Tien Nguyen $\mathrm{Minh}^{3}$, Do Quy-Diem ${ }^{4}$, Trung Nguyen Kim", \\ Thoa Dao Thi Kim ${ }^{6}$ and Tan Phan Minh,"* \\ ${ }^{1,3,4}$ Faculty of Chemical Engineering, Industrial University of HCMC, Viet Nam. \\ ${ }^{2,5,6}$ Faculty of Chemical Engineering, HCMC University of Technology, \\ Viet Nam National University. \\ ${ }^{7}$ Research Institute for Sustainable Energy, HCMC University of Technology, \\ Viet Nam National University. \\ *E-mail: pmtanbk@gmail.com
}

\begin{abstract}
This research shows the production of bio-based oil in green chemistry. Catfish fat was treated to refined catfish oil by physical processes. Degum of catfish fat was performed in cavitation equipment. The blending bio-lubricant from refined catfish oil was prepared base on the SAE $20 \mathrm{~W} 50$ engine lubricant formula. Thermogravimetric analysis (TGA) was used for determining the oxidation resistance of samples. The biodegradability of samples was studied by COD test and BOD test. The properties of materials and products were determined according to the TCVN standard and ASTM standard. The study finds that the efficiency of degumming of catfish fat was increased considerably in using cavitation technique. The optimal conditions of degumming were temperature at $40{ }^{\circ} \mathrm{C}$ and time of 3minutes. After physical treatment, refined catfish oil can be used as bio-based oil and the blend of biolubricant added 20 (wt.\%) refined catfish oil can meet the quality standards of SAE20W50 commercial lubricant nearly. Production of bio-based oil from catfish fat can develop sustainably because of its green nature as biological materials, environmentally friendly products, production processes that limit the use of chemicals and apply green technology.
\end{abstract}

Keywords: Catfish Fat, Cavitation, Bio-based Oil, Bio-lubricant

() RASĀYAN. All rights reserved

\section{INTRODUCTION}

Nowadays, the demand for lubricants in Vietnam and Asian countries increases. Meanwhile crude oil resources for the production of lubricants and fuels can be limited. On the other hand, waste lubricant is a big problem for the environment. This prompted scientists to consider the alternative and environmentally friendly materials. Vegetable oils can be one of the sources of renewable and biodegradable materials. Vegetable oils can used as bio-lubricant, such as palm oil, soybean oil, olive oil ${ }^{1}$. However, the oxidative stability and the ability to work at low temperatures of bio-lubricants were not high. Because vegetable oils contain certain impurities (gums, waxes) ${ }^{2}$. For the purpose of enhancing the features of bio-lubricant, some research mixed vegetable oils with additives. Soybean oil, rapeseed oil, castor oil or high oleic sunflower oil were mixed with improving viscosity additive (ethylene-vinyl acetate copolymer or ethylcellulose) and pour point depressant additive. The tribology properties of product were improved ${ }^{3}$. In other research, bio-lubricant was blended from canola oil, corn oil, and zinc dialkyldithiophosphate (ZDDP) additive. The result presented that, ZDDP was reduced the coefficient of friction for biolubricant ${ }^{4}$. The vegetable oil processing can be degummed, dewax and dry. Degum of vegetable oils was carried out in water with the extreme agitating system to increase the contact between oil and water because they are two dissolved phases ${ }^{2}$. In order to improve the performance of processing with insoluble phases, scientists have searched for advanced mixing techniques, such as mixing techniques of the

Rasayan J. Chem., 12(4), 2058-2064(2019)

http://dx.doi.org/10.31788/RJC.2019.1245289

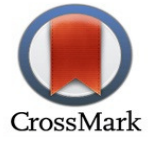


RASĀYAN J. Chem.

Vol. 12 | No. 4 |2058 - 2064| October - December | 2019

ultrasound power, mixing techniques of the cavitation energy. Preeti B. Subhedar and partner were carried out the heterogeneous reaction of waste cooking oil and methyl acetate in ultrasound device as reactor. Comparing with process carried out in classical stirring reactor, reaction performed on ultrasound equipment was not only decreasing time reaction (25 hours down to 3hours) and loading catalyst (6 wt.\% down to 3 wt.\%) but also increasing yields $(90.1 \% \text { rise to } 96.1 \%)^{5} .2014$, Ganesh L.Maddikeri et al applied hydrodynamic cavitation as reactor for reaction of waste cooking oil and methyl acetate. The effect of the process on cavitation was higher than that of process performed on ultrasound devices ${ }^{6}$. Hydrodynamic cavitation technique was applied to the synthesis biodiesel from palm olein and methanol by Lai fatt Chuah and partner. The conversion of reaction was increased and the time reaction was decreased clearly ${ }^{7}$. So it can say clearly that, in the heterogeneous reaction, it is the higher of the surfacing acreage of contacting phases, the faster of the reaction velocity and the higher of the efficiency. Some of the studies were carried out on vegetable oils materials; neither study on animal fats. Animal fats have a triglyceride structure similar to that of vegetable oils ${ }^{2}$. Viet Nam is one of the world's leading exporter of fillet catfish. Usually, the fillet portion is only accounted about $1 / 3$ of catfish weight. So fat, skin, head, bone are the by-products of catfish processing and fat accounts for the largest share ${ }^{8}$. The time before, the large number of catfish fats were discarded or used for animal food. In Viet Nam, only Sao Mai company produces cooking oils from catfish fat. So the catfish fat is an abundant and available resources in Viet Nam. Beside it, in the catfish fat degum,water and catfish fat was heterogeneous together ${ }^{2}$. So the main technological factor of degum can be the contaction of two phases. So in this study, the agitation base on cavitation technology was applied in degum of catfish fat. It can improve the effect of catfish fat degum.

Generally, the production of bio-based oil from catfish fat in this study can developsustainably because of its green properties such as, availableand biological materials, the friendly environmental product, the process of applying new techniques, limiting the use of chemicals.

\section{Material}

\section{EXPERIMENITAL}

Catfish fat was bought by Phuoc Thanh Agricultural Products Import Export Company Limited. Mineral base oil SN500 and some additives were provided from Petrochemical Hoa Viet Company in Dong Nai province, Viet Nam.

\section{General procedure}

The catfish fat processing involved three steps: degum, dewax and dry $^{2}$. Degum was assisted by a cavitation system which is presented in Fig.-1.

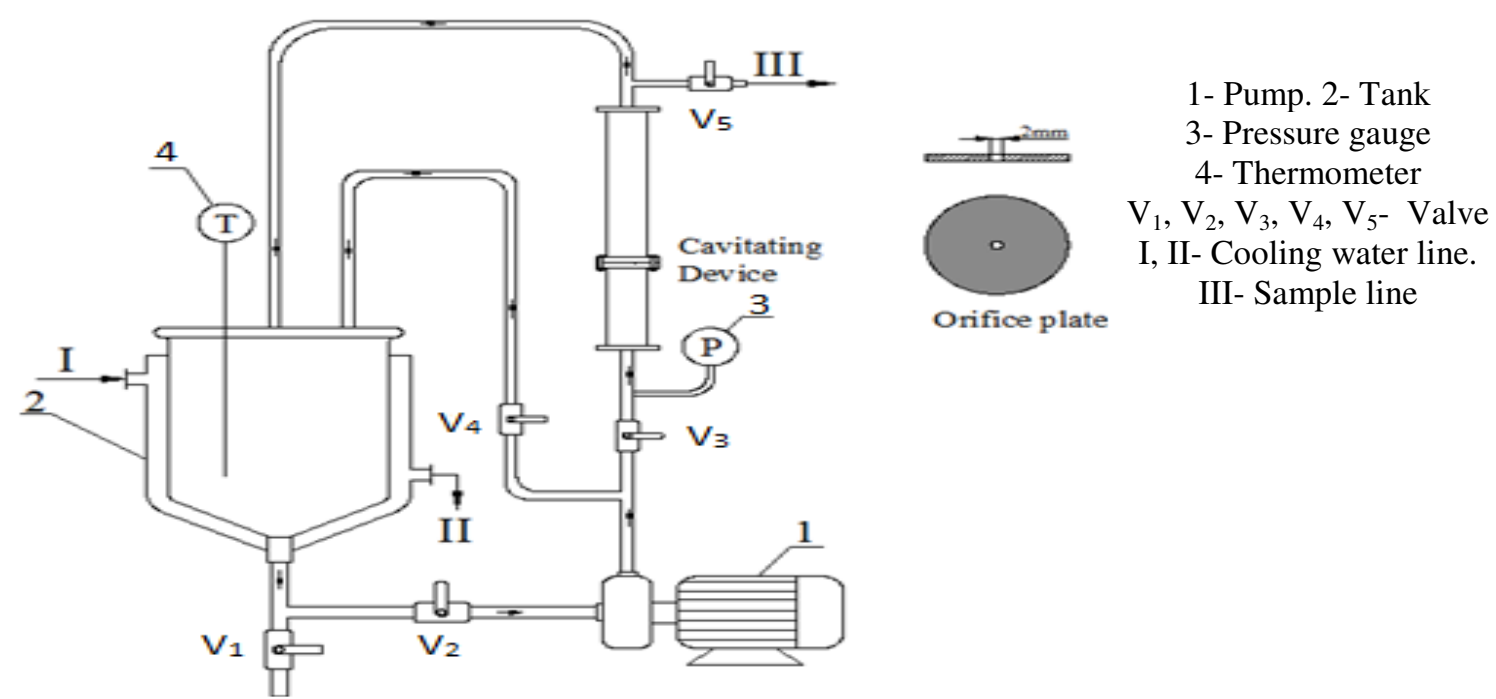

Fig.-1: The Cavitation System 


\section{Device Description and Equipment Operation}

The cavitation system is equipped with one $2 \mathrm{~mm}$ hole on an orifice plate ${ }^{7}$. Materials (waterand catfish fat) were fed to the tank -2 . The drain valve $V_{1}$ and recycle valve are closed, valves $V_{2}$ and valve $V_{3}$ are openned so the feed can be enterred the cavitation device by using the power of pump. The input pressure of feed was measured by the pressure gauge -3 . The flow pressure was dropped from the input pressure to normal pressure. By decreasing the pressure, liquid is heated and evaporated to form cavitation in the system. The temperature of system was recorded by using the thermometer -4 and controlled by using a cold / hot water flow from I to II.

\section{Procedureof Catfish Fat Processing}

Catfish fat degum was conducted by mixing water with catfish fat in the cavitation system. $5 \mathrm{~kg}$ catfish fat and water (2wt.\%) of catfish fat) was put in to the tank of cavitator. The pressure was set up at 60 psi. The temperature carried out in range of $\left(30{ }^{\circ} \mathrm{C} \div 60{ }^{\circ} \mathrm{C}\right)$. The time carried out in range of $(1$ minute $\div 7$ minute). When degum finished, mixture setled for 20 hours, valve $\mathrm{V}_{1}$ was openned todrainthe lower layer, collect the top layer as product and the product was determinated acid value according to potentiometric titration method - ASTM D664. Next, it is dewax. Dewax equipment is a cone-shaped cylindrical container, made of stainless steel. A mixing system consists of a 2-stage engine and paddle right in the center of the container. The container has an outer cooling jacket shell. The dewax was conducted by the cooling method. $5 \mathrm{~kg}$ of product of degum was put in to the dewax device. The mechanical stirrer was installed and speed of stirrer was set up at $120 \mathrm{rpm}$. Ice water and salt was added to the area of the cooling jacket of dewax divice. The temperature carried out range of $\left(8{ }^{\circ} \mathrm{C} \div 17^{\circ} \mathrm{C}\right)$. The time carried out in range of $\left(4\right.$ hour $\div 10$ hour). When cooling time completely, the mixture was heated to about $20{ }^{\circ} \mathrm{C}$, bottom valve opened to the mixture flowed into the filter by filtered cloth (hole diameter of cloth, $d=5 \mu \mathrm{m}$ ). The liquid oil passed to the filtration as product, it was determined the pour point according to the ASTM D97. After dewax, catfish oil was dried in vacuum drying equipment (pressure of vacuum was set at 0.1 atm) to receive refined catfish oil (RCFO). RCFO was determinated the water content according to the ASTM D95.

\section{Blending Bio-lubricant}

Firstly, the engine lubricant SAE20W50 was prepared from the mineral oils (SN500) and additives ${ }^{9}$. From the SAE20W50 lubricant formular, the additives was fixed, the SN500 was replaced by RCFO in range of 10 (wt.\%), 20 (wt.\%), and 30 (wt.\%) and these blends were coded 10BIO, 20BIO and $30 B I O$ respectively. Determination the properties of bio-lubricant blends according to the technical standards of commercial lubricants SAE20W50. Finally, the substitutability of bio-lubricants for mineral lubricants was assessedbase on the results of analytical results.

\section{Detection Method}

The potentiometric titration method carried out in 848 Titrino Plus - Metrohm, pH electrode in Industrial University of HCMC, Viet Nam $(I U H)$. TGA test was carried out in LINSEIS STA-PT 1600, under nitrogen, temperature in range of $\left(25^{\circ} \mathrm{C} \div 800{ }^{\circ} \mathrm{C}\right)$, heating rate at $10{ }^{\circ} \mathrm{C} /$ minute in Biomass laboratory of Research Institute for Sustainable Energy, University of Technology, HCMC National, Viet Nam. Biodegradability of samples were analyzed by biochemical oxygen demand (BOD) test and chemical oxygen demand (COD) test in which, sample of bio-based oil was diluted 10 times and samples of mineral base oil, bio-lubricant was diluted 100 times in distillated water. The properties of materials and products were determined according to the TCVN standard and ASTM standard in Petroleum Laboratory of Faculty of Chemical Engineering, University of Technology, Viet Nam National University HCMC, in Petroleum Laboratory of Faculty of Chemical Engineering,Industrial University of HCMC, Viet Nam.

\section{RESULTS AND DISCUSSION \\ Effect of the Time and the Temperature in Degum of Catfish Fat}

The results of experiments in degum are shown in Table-1. The data in Table - 1 shows that, the decreasing of acid value with increasing temperature and the time in range of $\left(30{ }^{\circ} \mathrm{C} \div 40{ }^{\circ} \mathrm{C}\right)$ and $(1$ 
minute $\div 3$ minute) respectively. The process efficiency was only slightly reduced when the temperature increased from $40{ }^{\circ} \mathrm{C}$ to $60{ }^{\circ} \mathrm{C}$ and the time increased from 3 minute to 7 minute at the system pressure value of $60 \mathrm{psi}$. The optimum conditions of degum are the time of 3 minutes and temperature of $40{ }^{\circ} \mathrm{C}$. This can explained that, in conditions of 3 minutes, $40{ }^{\circ} \mathrm{C}$, the contaction of water with hyrophilic compounds occurs fully, so the productivity of degum increased, it reached at the highest level. But the time and the temperature increased continuously, the emulsion of gums and water can be created and the formation of emulsion can be a problem in separation product.

Table-1: Effect of the Time and the Temperature on the Yield of Degum

\begin{tabular}{|c|c|c|c|c|c|}
\hline \multirow{5}{*}{$\begin{array}{c}\text { The time was } \\
\text { set at } 3 \\
\text { Minute }^{2}\end{array}$} & Temperature $\left({ }^{\circ} \mathrm{C}\right)$ & $\begin{array}{c}\text { Acid Number } \\
(\mathrm{mgKOH} / \mathrm{g})\end{array}$ & \multirow{5}{*}{$\begin{array}{c}\text { The } \\
\text { temperature } \\
\text { was set at } 50 \\
{ }^{\circ} \mathrm{C}\end{array}$} & $\begin{array}{c}\text { Time } \\
\text { (minute) }\end{array}$ & $\begin{array}{c}\text { Acid Number } \\
(\mathrm{mgKOH} / \mathrm{g})\end{array}$ \\
\hline & 30 & 2.915 & & 1 & 2.916 \\
\hline & 40 & 2.890 & & 3 & 2.890 \\
\hline & 50 & 2.895 & & 5 & 2.900 \\
\hline & 60 & 2.905 & & 7 & 2.903 \\
\hline
\end{tabular}

After degum, acid number of catfish fat decreased from $2.920(\mathrm{mgKOH} / \mathrm{g})$ down to $2.890(\mathrm{mgKOH} / \mathrm{g})$, decreased $1.03 \%$. Degum vegetables oils with water in mechanical agitator, the acid number decreased about of $0.1-0.4 \%$, in 40 minute, $60{ }^{\circ} \mathrm{C}^{2}$. So the effect of degum catfish fat in the cavitator reactor was better than that of vegetables oils degum in mechanical agitator. The temperature process decreased from $60{ }^{\circ} \mathrm{C}$ to $40{ }^{\circ} \mathrm{C}$ and more over we see that, performing degum catfish fat in the cavitator reduced the mixing time a lot, from 40 minutes down to 3 minutes (13.33 times). Using cavitator equipment gave better results because of its high mixing ability.

\section{Effect of the Time and the Cooling Temperature on Dewax}

The results of experiments in dewax are shown in Table-2. The data in Table-2 presents that, the pour point of product decreased in increasing of the cooling time in range of ( 4 hour $\div 8$ hour) and decreasing of cooling temperature in range of $\left(18{ }^{\circ} \mathrm{C} \div 12{ }^{\circ} \mathrm{C}\right)$. After dewax, the operation of catfish fat at low temperature can be improved because the pour point of catfish fat decreased from $20{ }^{\circ} \mathrm{C}$ to $9{ }^{\circ} \mathrm{C}^{10}$. When comparing to some bio-based oil such as coconut oil, rubber seed oil, the pour point of catfish fat is between the pour point of two bio-based oil, $\left(22{ }^{\circ} \mathrm{C} \div-9{ }^{\circ} \mathrm{C}\right)^{11}$. After the dewax, catfish oil was dried in vacuum drying cabinet to receive refined catfish oil. Vacuum presssure was set up $0.1 \mathrm{~atm}$ and drying time was 4 hour. The water content (v.\%) of RCFO was determinated by ASTM D95 and the resuilt was 0.01 (v.\%).

Table-2: Effect of the Time and the Temperature on the Yield of Dewax

\begin{tabular}{|c|c|c|c|c|c|}
\hline \multirow{5}{*}{$\begin{array}{c}\text { The cooling } \\
\text { temperature } \\
\text { was set at } \\
10^{\circ} \mathrm{C}^{2}\end{array}$} & $\begin{array}{l}\text { Time } \\
\text { (hour) }\end{array}$ & $\begin{array}{c}\text { Pour Point } \\
\left({ }^{\circ} \mathrm{C}\right)\end{array}$ & \multirow{5}{*}{$\begin{array}{l}\text { The } \\
\text { cooling } \\
\text { time was } \\
\text { set at } \\
8 \text { hour }\end{array}$} & $\begin{array}{c}\text { Temperature } \\
\left({ }^{\circ} \mathrm{C}\right)\end{array}$ & Pour Point $\left({ }^{\circ} \mathrm{C}\right)$ \\
\hline & 4 & 15 & & 9 & 9 \\
\hline & 6 & 12 & & 12 & 9 \\
\hline & 8 & 9 & & 15 & 12 \\
\hline & 10 & 9 & & 18 & 15 \\
\hline
\end{tabular}

\section{Blending Bio-lubricant}

The SAE20W50 engine lubricant formular was designed and it can be described in Table-3. Base on the SAE20W50 lubricant formular, bio-lubricant blends of 10BIO, $20 B I O$ and $30 B I O$ were prepared. Resuilts of determination the properties of RCFO, SN500, bio-lubricant blends and SAE20W50 lubricant blendare shown in Table-4 and Table-5 respectively.

Table-3: Composition of SAE20W50 Engine Lubricant Formular ${ }^{9}$

\begin{tabular}{c|c|c|c|c}
\hline \multirow{2}{*}{$\begin{array}{c}\text { Mineral Based Oil } \\
(\text { wt.\%) }\end{array}$} & \multicolumn{4}{|c}{ Additives \%(wt) } \\
\cline { 2 - 5 } & $\begin{array}{c}\text { Improving } \\
\text { Viscosity }\end{array}$ & $\begin{array}{c}\text { Improving } \\
\text { Alkalinity }\end{array}$ & $\begin{array}{c}\text { Pour Point } \\
\text { Depressant }\end{array}$ & Multifunctional Additives \\
\hline 85.938 & 6.218 & 1.854 & 1.255 & 4.735 \\
\hline \multicolumn{5}{|c}{2061}
\end{tabular}


RASĀYAN J. Chem.

Vol. 12 | No. 4 |2058 - 2064| October - December | 2019

Table-4: The Density, Flash Point, Pour Point, Kinematic Viscosity and Viscosity Indexof RCFO, SN500, BioLubricant Blends and 20W50 Lubricant Blend

\begin{tabular}{c|c|c|c|c|c|c|c}
\hline Properties & $20 \mathrm{~W} 50$ & $10 \mathrm{BIO}$ & $20 \mathrm{BIO}$ & $30 \mathrm{BIO}$ & SN500 & RCFO & $\begin{array}{c}\text { Standard Test } \\
\text { Method }\end{array}$ \\
\hline Density & 0.889 & 0.901 & 0.907 & 0.910 & 0.889 & 0.913 & ASTM D2896 \\
\hline Flash point $\left({ }^{\circ} \mathrm{C}\right)$ & 239 & 249 & 251 & 255 & 239 & 289 & ASTM D92 \\
\hline Pour point $\left({ }^{\circ} \mathrm{C}\right)$ & -20 & -16 & -12 & -8 & -6 & 8 & ASTM D97 \\
\hline $\begin{array}{c}\text { Kinematic viscosity } \\
(\mathrm{cSt})\end{array}$ & & & & & & & \\
$-40^{\circ} \mathrm{C}$ & 211 & 202.08 & 196.05 & 184 & 96.03 & 94.48 & ASTM D445 \\
$-100{ }^{\circ} \mathrm{C}$ & 21.5 & 22.20 & 22.42 & 22.71 & 11.59 & 12.03 & \\
\hline Viscosity index & 121.84 & 132.92 & 138.68 & 142.69 & 109.07 & 119.00 & ASTM D2270 \\
\hline
\end{tabular}

The data in Table- 4 shows that, some properties such as, density, flash point, kinematic viscosity (at 40 ${ }^{\circ} \mathrm{C}, 100{ }^{\circ} \mathrm{C}$ ) and viscosity index of RCFO were meet the technical requirements of mineral base oil SN500 and these properties of bio-lubricant blends were also meet the technical requirements of SAE20W50 lubricant. In the research of M.C Herna'ndez-Cruz and partners, chicken fat was treated by physical refining (gumming, bleached and fractionation). The density, viscosity $\left(\mathrm{mm}^{2} / \mathrm{s}\right)$ at $40{ }^{\circ} \mathrm{C}, 100{ }^{\circ} \mathrm{C}$ and viscosity index of chicken fat after physical refining was $0.899,37.25,8.18$ and $203.076^{12}$. When compare with other bio-based oils from vegetables oils, such as sunflower oil, rubber seed oil and coconut oil, the kinematic viscosity (at $40{ }^{\circ} \mathrm{C}, 100{ }^{\circ} \mathrm{C}$ ) and the viscosity index of refined catfish oil was higher ${ }^{11}$. In the research of Michael Bong Alang and partners, the synthesized biolubricant from Cameroon palm kernel seed had kinematic viscosity (at $40{ }^{\circ} \mathrm{C}, 100{ }^{\circ} \mathrm{C}$ ) and viscosity index of $509.80 \mathrm{cSt}, 30.80 \mathrm{cSt}$ and $120^{13}$. Although RCFO has a higher pour point temperature than that of SN500, the climate of Vietnam and Asian countries, the average temperature in winter may be over $10{ }^{\circ} \mathrm{C}$, so RCFO can use as bio-based oil. Beside it, in the blending bio-lubricants from RFCO, one note thing was added amout of pour point depressant additive to improve the ability to work at low temperatures of bio-lubricants. So it can say that, the ability of RCFO as a bio-based oil can be possible.

Some properties of samples such as, total base number (TBN), metal content, carbon conradson, oxidation stability and BOD/COD are shown in Table-5.

Table-5: The TBN, Metal Content, Carbon Conradson, Thermal Oxidation and BOD/COD of RCFO, SN500, IOBIO, 20BIO, $30 B I O$ and 20W50

\begin{tabular}{|c|c|c|c|c|c|c|c|}
\hline Properties & $\begin{array}{c}\text { SAE } \\
20 W 50\end{array}$ & $10 B I O$ & $20 B I O$ & $30 B I O$ & SN500 & RCFO & $\begin{array}{c}\text { Standard Test } \\
\text { Method }\end{array}$ \\
\hline TBN $(\mathrm{mgKOH} / \mathrm{g})$ & 10.2 & 8.9 & 8.1 & 7.6 & - & - & ASTM D2896-15 \\
\hline Metal content (\%wt) & 0.547 & 0.434 & 0.250 & 0.235 & 0.451 & 0.172 & ASTM 4628-16 \\
\hline $\begin{array}{c}\text { Carbon conradson } \\
(\% \mathrm{wt})\end{array}$ & 0.5200 & 0.4890 & 0.4792 & 0.4522 & 0.4990 & 0.2090 & ASTM D189 \\
\hline $\begin{array}{c}\text { Oxidation stability - } \\
\text { decomposition } \\
\text { temperature }\left({ }^{\circ} \mathrm{C}\right) \\
- \text { Onset } \\
-5(\text { wt. } \%) \\
-50(\text { wt. } \%) \\
-95(\text { wt. } \%) \\
-99(\text { wt. } \%)\end{array}$ & $\begin{array}{l}261 \\
315 \\
426 \\
511 \\
786 \\
\end{array}$ & $\begin{array}{l}239 \\
290 \\
402 \\
471 \\
507 \\
\end{array}$ & $\begin{array}{l}235 \\
284 \\
394 \\
461 \\
594 \\
\end{array}$ & $\begin{array}{l}231 \\
280 \\
400 \\
468 \\
522 \\
\end{array}$ & $\begin{array}{c}258.5 \\
320 \\
435 \\
521 \\
748.5 \\
\end{array}$ & $\begin{array}{c}200 \\
294.5 \\
319 \\
347 \\
361 \\
\end{array}$ & TGA method \\
\hline $\begin{array}{c}\mathrm{BOD} \\
\left(\mathrm{mgO}_{2} / \mathrm{mL}\right)\end{array}$ & 161 & 13.7 & 13.2 & 12.8 & 158 & 11.5 & $\begin{array}{c}\text { TCVN 6001- } \\
1: 2008\end{array}$ \\
\hline $\begin{array}{c}\mathrm{COD} \\
\left(\mathrm{mgO}_{2} / \mathrm{mL}\right)\end{array}$ & 712 & 62.2 & 43.9 & 42.7 & 700 & 37.4 & $\begin{array}{c}\text { SMEWW } \\
2012(5220-\mathrm{D})\end{array}$ \\
\hline
\end{tabular}

The change of TBN of samples decreases in order to $10 B I O, 20 B I O, 30 B I O$. This can explain that the RCFO can be contacted amount of free fatty $\mathrm{acid}^{2}$, it can cause the decreasing the TBN of bio-lubricant 
blends. In this study, the total base number (TBN) of engine lubricant SAE 20W50 is higher than that of bio-lubricant blends. However, the quality standard of commercial SAE20W50 lubricant specified TBN is $\min 6.9(\mathrm{mgKOH} / \mathrm{g})^{14}$. So TBN of bio-lubricant blended from RCFO can meet the quality requirements of lubricant commercial SAE20W50.

From the metal content and the carbon conradson content of samples show that, the cleaning burning ability of RCFO and bio-lubricants may be higher than that of SN500 mineral base oil and engine lubricant SAE20W509. Because, both metal content and the carbon conradson content of mineral base oil SN500 and SAE 20W50 lubricant are higher than that of RCFO and bio-lubricants. It can explain that mineral base oil was produced from heavy distillation of crude oil, it can contain amount of metal and residue ${ }^{15}$.

In the result of TGA test, the decomposition temperature of samples was decreased in order of $10 B I O$, $20 B I O, 30 B I O$. This can be explained by there fining catfish fat process is simple, it is included filter, degum (hydration), dewax and dry. After physical treatment, some impurities (sediment, gum, wax, and water) were removed but structure of catfish fatwas not converted. Therefore, the amount of unsaturated compound contained in RCFO can make the heat resistance of it was not higher than that of mineral oil $\mathrm{SN} 500^{2}$. However, in blending bio-lubricant, adding amount of additives were improved the oxidationresistant of them significantly. The results of TGA were showed details, the stable thermal of all blends of bio-lubricants created at $\left(231{ }^{\circ} \mathrm{C} \div 239{ }^{\circ} \mathrm{C}\right)$. In the range of $\left(280{ }^{\circ} \mathrm{C} \div 290{ }^{\circ} \mathrm{C}\right)$, bio-lubricant blends were decomposed by $5 \%$ (wt) and samples bio-lubricant were decomposed $95 \%$ (wt) in range of $\left(461{ }^{\circ} \mathrm{C} \div\right.$ $471{ }^{\circ} \mathrm{C}$ ). These temperatures of SAE $20 \mathrm{~W} 50$ lubricant were $261{ }^{\circ} \mathrm{C}, 315^{\circ} \mathrm{C}$, and $511^{\circ} \mathrm{C}$. So the difference in temperature decomposition of samples is not too large. When compared with other biobased oils or bio-lubricants, thermogram of RCFO and bio-lubricant in this study can be similar to those of them. After physical refining, chicken fat started decomposed below $274{ }^{\circ} \mathrm{C}$ and it was decomposed up to 98 $\%$ (wt) in $489{ }^{\circ} \mathrm{C}^{13}$. In the research of Amith Aravin, stable thermal under oxygen environment of biolubricant from rubber tree seed oil was $250{ }^{\circ} \mathrm{C}$ and after $300{ }^{\circ} \mathrm{C}$, decomposition of bio-lubricant occurred strongly ${ }^{12}$.

The data of the BOD test and COD test of samples in table -5 show that the biodegradability of RCFO and bio-lubricants may be easier than that of mineral base oil SN500 and SAE20W50 lubricant. The demand for biochemical oxygen and chemical oxygen in water of mineral base oil SN500 and engine lubricant SAE20W50 are higher than that of RCFO and all blends of bio-lubricant ${ }^{11}$.

From above the results and discussion find that the properties of $20 B I O$ blend can meet nearly the technical requirements of commercial SAE20W50, so it was chosen as the optimal bio-lubricant formulation in this study.

\section{CONCLUSION}

The efficiency of the treatment Catfish fat to bio-based oil increased significantly in using a cavitation reactor. Efficient of degumming achieved the highest in 3 minutes, $40^{\circ} \mathrm{C}$. The pour point of product of dewaxing decreased from $20{ }^{\circ} \mathrm{C}$ down to $8{ }^{\circ} \mathrm{C}$. The analysis results showed that refined catfish oil can be used as bio-based oil. Because refining catfish oil can not only meet the properties according to the mineral base oil standards but it is also easily biodegradable. The blend of bio-lubricant was added 20 (wt.\%) of refined catfish oil can use as a replacement SAE20W50 engine lubricant. The potential for the development of bio-lubricant production from catfish fat is enormous because of its sustainability.

\section{ACKNOWLEDGMENT}

The authors would like to express their sincere thanks to the Industrial University of HCMC, 12 Nguyen Van Bao street, Go Vap District, HCMC, Viet Nam for the financial support of the grant number 19/HĐ signed on April 12, 2017. Contract code: 171.4091.

\section{REFERENCES}

1. P. D. Srivyas and M. S. Charoo, Tribology in Industry, 40, 4, (2018), DOI: 10.24874/ti.2018.40.04.0

2. L. Honary and E. Richter, Biobased Lubricants and Greases, John Wiley \& Sons, Chichester, p.25-48, (2011), DOI: $10.1002 / 9780470971956$

3. L. A. Quinchia, M. A. Delgado, C. Valencia, J. M. Franco and C. Gallegos, Industrial Crops and Products, 32, 3, (2010), DOI: 10.1016/j.indcrop.2010.07.011 
RASĀYAN J. Chem.

Vol. 12 | No. 4 |2058 - 2064| October - December | 2019

4. M. A. b. Azhari, M. F. b. Tamar, N. R. b. M. Nuri and M. R. b. Yusoff, ARPN Journal of Engineering and Applied Sciences 10, 15, (2015).

5. P. B. Subhedar and P. R. Gogate, Ultrason Sonochem, 29, 67(2016), DOI: 10.1016/j.ultsonch.2015.09.006

6. G. L. Maddikeri, P. R. Gogate and A. B. Pandit, Fuel, 137, 285(2014), DOI: 10.1016/j.fuel.2014.08.013

7. L. F. Chuah, S. Yusup, A. R. Abd Aziz, A. Bokhari, J. J. Klemeš and M. Z. Abdullah, Chemical Engineering and Processing: Process Intensification, 95, 235(2015), DOI:10.1016/j.cep.2015.06.018

8. T. M. Phu, T. T. Tien, N. L. A. Đao and T. T. T. Hien, Can Tho University Journal of Science, Viet Nam, 1, (2014).

9. M. Torbacke, Å. K. Rudolphi and E. Kassfeldt, Lubricants, John Wiley \& Sons Chichester, p.93-108, (2014), DOI:10.1002/9781118799734

10. M. Torbacke, Å. K. Rudolphi and E. Kassfeldt, Lubricant, John Wiley \& Sons, Chichester, p.20-29, (2014), DOI:10.1002/9781118799734

11. A. Aravind, M. L. Joy and K. Nair, Industrial Crops and Products, 74, (2015), DOI:10.1016/j.indcrop.2015.04.014

12. M. C. Hernández-Cruz, R. Meza-Gordillo, B. Torrestiana-Sánchez, A. Rosales-Quintero, L. M. C. Ventura-Canseco and J. H. Castañón-Gonzáles, Fuel, 198, 42(2017), DOI:10.1016/j.fuel.2016.12.039

13. M. B. Alang, M. K. Ndikontar, Y. M. Sani and P. T. Ndifon, Green and Sustainable Chemistry, 8(3), 275(2018), DOI:10.4236/gsc.2018.83018

14. P. P. J. S. Company, TCCS 01: 2012/ PLC, Petrolimex Petrochemical Joint Stock Company, Ha Noi, Viet Nam, (2012).

15. M. Torbacke, Å. K. Rudolphi and E. Kassfeldt, Lubricants John Wiley \& Sons Chichester, p.45-56, (2014), DOI: $10.1002 / 9781118799734$

[RJC-5289/2019] 